\title{
Leona Vingativa: uma estrela da convergência
}

\author{
Ingrid Fernandes Ruela*, Pedro Maciel Guimarães Junior.
}

\section{Resumo}

O objetivo deste trabalho é atualizar a compreensão do fenômeno das estrelas de cinema ao contexto da produção audiovisual brasileira contemporânea. Para isso, analisamos os quatro episódios da websérie Leona Assassina Vingativa, à luz dos parâmetros elaborados por Edgar Morin no prefácio à terceira edição da obra Les Stars, que se desdobraram nos seguintes eixos de análise: a que demandas a existência da obra responde?; quais os códigos estéticos empregados nos vídeos?; e, por fim, como se dá a relação entre a instância realizadora e a receptora?

\section{Palavras-chave:}

Star system, Web 2.0, história e estética do audiovisual brasileiro.

\section{Introdução}

Marylin Monroe. Mesmo que não tenham visto seus filmes, todos conhecem este nome. Para Edgar Morin1, a morte da atriz em 1962 é um marco que encerra a terceira fase do star system, a última analisada por ele. A fim de avançar com a compreensão sobre como nascem as estrelas no audiovisual brasileiro contemporâneo em tempos de "convergência midiática"2, elegemos como objeto para esta pesquisa a websérie Leona Assassina Vingativa. Os primeiros três capítulos viralizaram na Internet em 2009 no nicho LGBTQ+, encontrando no público alguns fãs que se incorporaram ao processo de produção. Em 2017, o quarto episódio foi lançado na internet e, logo depois, exibido na programação de importantes festivais de cinema, a exemplo da Mostra de Cinema de Tiradentes (2018). A repercussão reinscreveu Leona na cena audiovisual queer e a catapultou para participar de filmes e séries de TV, como a Cine Barato do canal GNT.

Esta ascensão na cadeia produtiva é um dos critérios estabelecidos por Morin para que uma atriz seja considerada uma estrela. Além deste, é necessário que haja osmose entre ator e personagem e que não haja absorção do ator pelo personagem. Assim sendo, Leona Vingativa é uma estrela. Mas, diferente de Monroe, a depender do meio, ninguém conhece este nome. Por quê? Como se estruturam a produção e a distribuição de seus vídeos? Quais são as formas estéticas empregadas que permitiram uma ampla circulação dos vídeos na Internet? $E$ mais: em tempos de engajamento e colaboração do usuário no processo de produção de conteúdo, como se articula a comunidade de fãs do trabalho de Leona? É ao redor destas e de outras questões que o presente trabalho se debruça.

\section{Resultados e Discussão}

Ainda que a Indústria Cultural siga desempenhando a mesma função descrita por Adorno e Horkheimer em $1947^{3}$, de lá para cá muita coisa mudou. E para entender como Leona Vingativa se inscreve dentro do strar studies hoje, é necessário primeiro situá-la em seu contexto de desenvolvimento da técnica de produção e distribuição dos produtos culturais. Assim, eu parti da definição do conceito de Web 2.0 para adentrar na interpretação de Henry Jenkins sobre as causas do desejo que a audiência deste período tem em interagir, recriar e até mesmo redirecionar o conteúdo para outros formatos e plataformas. Aqui começamos a entender por onde se organiza o fio condutor que orienta as escolhas estéticas da obra analisada: diante de um canal de comunicação direto com o realizador, os fãs apresentam suas demandas sem mediações. O emprego da trilha sonora da personagem Paola Bracho de La Usurpadora aos vídeos de Leona Vingativa foi uma intervenção elaborada por um fã e é um exemplo disso.

O uso dos códigos melodramáticos ${ }^{6}$, no entanto, não começou aí. Leona se apropria destas normas genéricas desde o primeiro vídeo para compor seu personagem, seu registro de atuação e a mise en scène de um modo geral. Isto, ao lado da narrativa de caráter seriado, é uma sofisticada estratégia de fidelização do público. Mas, diferente do melodrama clássico e de suas variações exibidas na televisão, a intensa movimentação e o apelo visual e sonoro ganham na websérie o elemento suplementar da estética camp. Ao propor este produto para um nicho consumidor pobre de referências queer, ser nomeada como "deusa" é apenas um passo, já que, no limite, a grande demanda deste público é sentir-se representado e ter seu lugar de representação garantido. Ao fazer isso com as próprias mãos Leona exemplifica, aos olhos do star studies latinoamericano, uma nova estratégia de marketing para atrair espectadores e vender um estilo de vida.

\section{Conclusões}

O objetivo deste trabalho, ampliar as perspectivas sobre - caráter da celebridade no audiovisual brasileiro contemporâneo, se realizou. Para dar conta da análise do objeto Leona Vingativa, foi necessário recorrer a diferentes perspectivas teóricas, sobre os distintos meios de comunicação. Só assim, pude entender o que há de novo realmente e o que são dilemas requentados da história de outros meios, ademais da Indústria Cultural. Ao que parece, os estudos sobre as novas mídias e a cultura da convergência devem se orientar por aí. Nesse sentido, o processo desta investigação introduziu esta nova questão metodológica, que pode nos render futuramente outros projetos de pesquisa no campo.

\footnotetext{
${ }^{1}$ MORIN, E. As Estrelas de Cinema. Lisboa, Livros Horizonte: 1980.

2 JENKINS, H. Cultura da convergência. São Paulo: Aleph, 2009.

3 ADORNO, T. W.; HORKHEIMER, M. Dialética do Esclarecimento. Rio de Janeiro: Jorge Zahar Editor, 1985.

${ }^{4}$ O'REILLY, Tim. Web 2.0 compact definition: trying again. O’Reilly Radar, 12 out. 2006.

${ }_{6}$ XAVIER, I. Melodrama ou a sedução da moral negociada Novos Estudos CEBRAP, n. 57, p. 81-90, jul. 2000.

${ }^{7}$ SONTAG, S. Notas sobre o "Camp”. 1964.
} 